\title{
The Educational Patterns for Intermarriage Children Between Dayak Ethnic and Javanese Ethnic
}

\author{
Mardiana $^{1}$, Tri Marheni Pudji Astuti ${ }^{2}$, Suyahmo $^{3}$, Triwaty Arsal ${ }^{4}$ \\ ${ }_{1,2,3,4}$ Social Science Education Study Program, Universitas Negeri Semarang, Indonesia \\ Corresponding email: mardianaleona@gmail.com
}

\begin{abstract}
The background to this research is the occurrence of mixed marriages between Dayak ethnic and Javanese ethnic. This results in problems starting from differences in religion, culture, language, which affect the pattern of education given to children born. This aim of this research to analyze the educational patterns of children of the type of education. The purpose of this study is to analyze children's education patterns, types of education in intermarriage between Dayak ethnic and Javanese in Tanjung Sari Village. The research uses a qualitative approach to the case study method. To collect the data through interviews, observation, and documentation for the intermarried couple, parent, children of intermarriage, community leader, and traditional leader. These results reveal that the pattern of education given to children of intermarriage is the collaboration between Javanese and Dayak, and is purely a mixture of Javanese. Formal education obtained by children of mixed marriages between Dayak ethnic and Javanese ethnic group consists of primary education, secondary education, and higher education. Non-formal education starts from an early age and basic education through the Al-Quran Education Park and tutoring in the surrounding environment. Informal education is given from birth with the inculcation of social, cultural and religious values.
\end{abstract}

Key word $\quad$ : Education for children, intermarriage, Pattern of Child Education

\section{Introduction}

Tanjung sari village from research location has a kinds of ethnic. The ethnic consist of Dayak, Malay, Javanese, Tionghoa, Madura, Bugis, Padang, Sundanese and etc. has different language, tradition, norm and tradition.

The terminology of Dayak is to point out the people nom muslim or non Malay which is the original people in Borneo. The tehnical term start from final century 19 in context the colonial people command to take sovereignty a quarter Borneo territory. According to the Department of Education and Culture Part of the Project for the Study and Development of East Kalimantan Cultural Values, Kaderland, Dutch scientists were the first to use the Dayak technical term from the conclusions (Maunati, 2004: 59). The history of outsider came in to borneo happen at 1880 untill 1940 masehi as a worker send from Hindia Belanda government although wish to bump form it self (Thamrin, 1988).

Background of language, cultural and religion has not barrier to do ethnic intermarriage Hariyono (1993:17) said that intermarriage the peak of assimilation, it is mean intermarriage. Intermarriage give explanation about united the soul, personality, characteristic and behavior from two human being from the different gender and different ethnic. The people of Tanjung Sari Village and intermarried couple respect each other in ethnic, cultural and religious differen; therefore, there has been the cultivation of multicultural value. In line with the result of Slamet (2017) research shows that multicultural education can be implemented in a family environment, beside that it can be inserted through learning activitie in school.

The difference between interbreeding languages, cultural and religion often make a difference in problem for married couples themselves even though the whole family and give effect to children. Every family from mixed marriages has their own way to build a household and husband and wife also have different ways to educate children because they come from different ethnicities. Every family of mixed marriages has their own way of building a household and the husband and wife also have different ways of educating children because they come from different ethnic. This, indirectly, forces children to make decisions in terms of choosing. Like by choosing one of the pure mixed education patterns of Dayak or Javanese. However, it is not uncommon for children to choose education that comes from a majority ethnicity even though children admit that they must follow the lineage of the father. 
The family obligation give children birth education quality appropriate necessary and educational expansion easy to understand for children, apprehend and take a attitude from differences of background, language, cultural and the religion from the parents. Based on the explanation that has been explained, it can be drawn several problems, namely how the pattern of education, and the type of children's education in mixed marriages between Dayak ethnic and Javanese ethnic. The purpose of the study was to analyze the pattern of education and the type of education of children from mixed marriages between Dayak ethnics and Javanese ethnic in Tanjung Sari Village,
Melawi Regency. This research is expected to be useful for couples to intervene in order to provide the best and quality education, and children to intermarry in order to get education that is in accordance with the needs and development of children in accordance with the goals of national education.

\section{Methods}

This research uses qualitative approach used case study. The population of research use eight people. Which is shown in the table below: four intermarriage couple, parent or family from intermarriage, a figure of society.

Table 1. Identity of reseach source

\begin{tabular}{c|l|l|l|l|l}
\hline No & \multicolumn{1}{c|}{ Name } & Age & \multicolumn{1}{c}{ Ethnic } & Religion & \multicolumn{1}{c}{ Description } \\
\hline 1 & $\mathrm{Al}$ & 45 & Dayak & Moslem & Husband \\
& $\mathrm{Jm}$ & 38 & Jawa & Moslem & Wife \\
2 & $\mathrm{Ag}$ & 47 & Dayak & Moslem & Husband \\
& $\mathrm{Ni}$ & 40 & Jawa & & Wife \\
3 & $\mathrm{Mn}$ & 40 & Jawa & Moslem & Husband \\
& $\mathrm{Jy}$ & 45 & Dayak & Kristen & Wife \\
4 & $\mathrm{Sn}$ & 60 & Jawa & Moslem & Parent \\
5 & $\mathrm{By}$ & 24 & Dayak & Moslem & Child \\
6 & Ec & 24 & Dayak & Moslem & Child \\
7 & Wd & 10 & Dayak & Moslem & Child \\
8 & Tf & 50 & Jawa & Moslem & Public figure \\
\hline
\end{tabular}

The research used purposive sampling technique that is the sample is selected from the interview, observation, and documentation. The validity to collected of the data used extension observation, diligence increase, and triangulation. The technique data analyze in this research used interactive analyze technique according to Miles dan Huberman (Creswell, 2014: 274-284; Sugiyono, 2014: 91-99), consist of four-step, that are: (1) collecting the data, (2) data reduction, (3) presentation of data, (4) and conclusion.

\section{Results and Discussion}

\section{Pattern of Child Education in Dayak and Javanese Ethnics Mixed Marriage} Intermarriage related to cultural assimilation because related with interaction both of different cultural. Intermarriage do between dayak ethnic with javanese ethnic can see among some thing love and commitment. Based on intermarriage couple with love all thing can solved and adjust from the couple have efort,interoretation, toleration and respect to differences and commonuty around the area.
Marriage according Law No 1 Year 1974 marriage is spritual between a man and woman as a couple with purpose to family form (household) happy and based on divinity of everlasting.

A family is a group of people consisting of father, mother, children, grandfather, grandmother and all people who have the same bloodline. That is, the family is used for a group of people who live together, or a group of people who live in a large house (family home) that is related to blood relations or marriage, living together or associating with each other for a common purpose (Wilson 1947).

A family has a place to live and raise children. in other words, a family is a social group characterized by a place to live, economic cooperation and reproduction. The people who belong to the family are the father, mother, and children. So, the family is where everyone can relate to each other and is the most important primary group in society (Blood 1972; Khairuddin 2002). 
Based on the results, researchers obtained results regarding children's education patterns in mixed marriages between Dayak ethnics and Javanese ethnic. The educational pattern provided by intermarried couples between Dayak ethnics and Javanese is education collaboration between Dayak ethnics and Javanese and purely mixed from Javanese. Education collaboration between Dayak ethnics and Javanese means that children receive education on cultural, social, language, and ethical values from both ethnicities, namely Dayak and Javanese ethnicities. Pure Javanese mixture means that children get more education from parents, namely mothers or fathers from Javanese ethnicity. This is because the background of the residence is mostly Javanese. Educational patterns generated from interviews with children of intermarried couples between Dayak ethnics and Javanese ethnic are shown in table 2 below:

Table 2. Statement about the pattern of children's education in inter-ethnic mixed marriages

\begin{tabular}{|c|c|}
\hline Education Pattern & Statement on Education Patterns \\
\hline $\begin{array}{ll}\text { Collaboration between } & \text { Dayak } \\
\text { ethnics and Javanese ethnic } & \end{array}$ & $\begin{array}{l}\text { I live in Kalimantan and grew up in Kalimantan, so I } \\
\text { joined the ethnic group. I never grew up in Java in } \\
\text { Kalimantan, so I automatically joined you. I honestly } \\
\text { can't speak father's language and the language of my } \\
\text { mother and other people's language. In fact, I have } \\
\text { mastered the language because I work there and the } \\
\text { majority of my friends are people, the environment } \\
\text { where I live and I have long been in Central } \\
\text { Kalimantan, so it can be a Dayak language. }\end{array}$ \\
\hline Pure mixed Javanese ethnicity & $\begin{array}{l}\text { The culture that is often planted is Javanese ethnicity } \\
\text { because there is also the Javanese environment. You } \\
\text { never taught the Dayak language so you followed the } \\
\text { National language. Javanese also can't say it but if you } \\
\text { speak Javanese you know. }\end{array}$ \\
\hline
\end{tabular}

The statement from Table 2 shows that acculturation and assimilation have occurred. Children admit that they are following the line of the father, but children are more familiar with the language and culture of the mother and prefer to use Indonesian. The results of research conducted by Barus 2011, showed that couples intermarried between Indonesian women and foreign men preferred the pattern of education originating from you, namely international standard education because they wanted their children to get the same education as foreign education. Every parent wants and provides the best education for their children with different programs and patterns for each partner. Married couples intervening between Dayak ethnics and Javanese ethnic give children freedom about what they want in accordance with the values and norms that apply. Like the research conducted by Taubah 2015, Sudarsana 2018, Munjahid 2018 that the pattern of education given to children by using patterns or methods of religious education patterns such as this is intended to form children to become faithful and devoted people to God Almighty, and noble includes ethics, morals, manners, spirituality and practice in everyday life.

The results of the above research all refer to the functions and objectives of the National Education System No. 20 of 2003 which aims to develop the potential of students to be faithful and fearful people of God Almighty, noble, healthy, knowledgeable, capable, creative, independent and become a democratic and responsible citizen.

Mixed marriages have adopted functions as the family, namely according to Gadlin (1990), Horton and Hunt (1992) see family as the smallest unit of society which has the following functions: affective function, socialization function, reproductive function, protection function, economic function, function education, social supervision function. In the educational function is the duty of parents to provide knowledge and skills to children born, married couples intervene between Dayak ethnics and Javanese ethnic in Tanjung Sari Village also provide decent and quality education to the children who are born. 


\section{Type of Child Education}

Education is part of effort and planned to create situation of study and process of learning although the participation educate activate to develop personal potential to have spritual strengh, personal control, characteristic, shrewdness, good moarals, along with skill society need, nation and state.

The education for children intermarriage between Dayak ethnic and Jvanese ethnic at Tanjung Sari village same with couple not intermarriage, the children get a good education appropiate, scalffold and children interest.in this thing as parent give children instruction to choose school or collage, the children give oppotunities to choose what they want. Becaus all the the citizen have right and obigation not seeind differces related to Pasal 5, ayat 1 Undang-Undang Sistem Pendidikan Nasional said that : "every citizen have same right to get equality of education ".

The education track as place to educate participation expand froam the potential personalin process appropiate with education purpose.at UU No. 20 tahun 2003 Pasal 13 ayat 1 said that formal education, non-formal dan informal. Be in the process of education the children get from the parent intermarriage between Dayak ethnic and Javanese ethnic at Tanjung Sari village, the are : formal education, non formal and informal education.

\section{Formal education}

Formal education as education track appropriate arranged with curriculum held in the schools. The educational track have scaffold , start from basic education, intermediate education, advanced education and collage. Based of the operator already arranged by government regulation Nomor 66 Tahun 2010 about change new rules about government regulation especially Pasal 60 Ayat 1.

\section{a. Nonformal education}

Non fomal education according to Pasal 1 Ayat 12 Undang-Undang Nomor 20 Tahun 2003 about educational system, the educational track out of formal education to use structural and step by step. Nonformal education many happen from kindergarten, along with basic education, for example TPA or educational AL-Quran, has many mosque and weekend school at church. The children from intermarriage between Dayak ethnic and Javanese ethnic at Tanjung Sari village start at kindergarten at AL- Quran education and Anak-anak dari pasangan amalgamasi antar etnis Dayak dengan etnsi Jawa di Desa Tanjung Sari mendapatkan pendidikan norformal dimulai dari usia dini dan pendidikan dasar melalui Taman Pendidikan Al-Quran, dan toutority educatiin around the area.

\section{b. Informal education}

Informal education as education track from family and circle from independent learning activity already aware ang obligation. The result from informal education is same with formal and nonformal education after educate participant appropiat to granted national standardiziation.

The couple from intermarriage couple between Dayak ethnic and Javanese ethnic at Tanjung Sari village give informal education to children start at kindergarten to emphasize at the social cultural and religion. Remember from the differences background cultural, language and religion in order to children have spiritual religion strength, characteristic personal, and personal tosolve a problem.

Three of education area in formal, non formal and informal has many effect toward development and people success education. The renewal in this study is that intermarried couples between Dayak ethnics and Javanese who have different religious, linguistic and cultural backgrounds can carry out their functions as a family, namely the educational function by providing education in accordance with the education path, namely formal, informal and non-formal education with implementing Dayak and Javanese collaboration education patterns, purely a mixture of Javanese in every educational path in accordance with its function.

The third education areas is more important and to determines the success of formal education and formal education is formal informal education (education society). In this area them are associate with society has kind characteristic and personality. The childrens must known to the application result from family education and school in infornal educational society a individual will make certain about attitude, engange in deliberations and etc. The learning that is obtained from an individual not only comes from one educational environment but from the three educational environments so that between each 
other perfect each other and eventually will produce an ideal upbringing or in other terms, a human being will be produced (perfect human use for the nation and religion.

The learning explicit a person get not only just from a educational society, rathet from three of educational society that from unit with another unit to complete and the finally has the ideal education result or in terminology has a kamil human product (a human has perfect beneficial for nation and religion).

\section{Conclusion}

The pattern of children's education in mixed marriages between Dayak ethnics and Javanese is divided into two, namely education on collaboration between Dayaks and Javanese, meaning that children receive education on the cultural, social, language, and ethical values of the two ethnicities, namely the Dayak and Javanese ethnicities. Pure Javanese mixture means that children get more education from parents, namely mothers or fathers from Javanese ethnicity.

The type of children's education given by parents of mixed marriages between Dayak ethnics and Javanese ethnic groups, namely proper education is the same as the children of other unmarried marriages. Formal education from elementary school, senior high school to college. Informal education is given from birth with the inculcation of social, cultural and religious values. Non-formal education starts from an early age and basic education through the Al-Quran Education Park and tutoring in the surrounding environment.

\section{References}

Arif, M. J. Akien. 1993. "Kehidupan Sosial Ekonomi Orang Dayak", Dalam: Kalimantan Review, Nomor 03 Tahun II, Januari-April. Pontianak: LP3ESInstitut of Dayakology Research and Development.

Blood, Robert O, Jr. 1972. The Family. New York: The Free Press.

Barus Rehia.K.I, Simatupang I, Noviyanti F.R. 2011. Pengaruh Komunikasi Antara Budaya Dalam Keluarga Kawin Campur Terhadap Pola Mendidik Anak
Di Komplek Setia Budi Indah. Jurnal Ilmu Sosial 4(2), 154-161.

Duvall, E.M. dan Miller B.C. 1985. Marriage and Family Development, New York. Harper \& Row Publishers.

Hariyono, P, Kultur Cina dan Jawa. 1993. Pustaka Sinar Harapan, Jakarta.

Horton, Paul B dan Hunt, Chester L. 1992. Sosiologi Jilid 2. Di Indonesiakan oleh Aminuddin Ram dan Tita Sobari. Jakarta: Penerbit Erlangga.

Khairuddin, H. 2002. Sosiologi Keluarga. Penerbit : Liberty. Yogyakarta.

Lewis, R., Yancey, G., \& Bletzer, S.S. 1997. Racial and nonracial factors that influence spouse choice in black/white marriages. Journal of Black Studies, 28(1), 60-7

Mac. Iver and Page. Charles H. 1952. Society; An Introduction Story Analysis. Macmillan Limited \& Co. London.

Miles and Huberman. 1992. Qualitative data Analisis. London: Sage Publication.

Murdock, George Peter. 1949. Social Structure. The Macmillan Company. New York.

Munjahid, Kuswanto H. 2018. Pola Pendidikan Humanis Religius Pada Rumah Pintar "PIJOENGAN" Bantul Yogyakarta. Jurnal Cendikia. 16(1) : 147-165

Parsons, Talcott. Robert F. Bales. 1955. Family, Socialization and Interaction Process. The Free Press. New York. Collier Macmillan Limited. London.

Sudarsana I Ketut. 2018. Implementasi Pendidikan Informal Hindu Dalam Menjaga Pola Komunikasi Remaja Pada Pergaulan Sehari-hari. Jurnal Komunikasi XII(1) : 40-50.

Slamet, Masrukhi, Haryono, Wasino. 2017. The Implementation of Multicultural Values in The Educational Institution. The Journal of Education Development. 5(1) : 118-127.

Taubah.M. 2015. Pendidikan Anak Dalam Keluarga Presfektif Islam. Jurnal of Islamic Education. 3(1), 109-136.

Thamrin, Khazin, Mohd. 1988. Orang Jawa di Borneo Utara: Satu Nota Awal. Jurnal Jebat 16, Hal:123-136.

Wilson, Adrian. 1947. Family. Tavistock Publications. London-New York. 